\title{
943 傾斜機能平板の熱曲げ曲率から材料組成分布を同定する逆問題解析
}

（物性值の温度依存性を考慮した場合）

Inverse Analysis of Material Composition Distribution from Curvature of Thermal Bending in FGM Plate

(Temperature Dependency of Mechanical Properties)

正菅野 良弘（岩手大工）。 ○学、晴山 裕貴（岩手大工）正 星 聖（日産）

Yoshihiro SUGANO, Iwate University, 4-3-5, Ueda, Morioka, Iwate

Yuuki HAREYAMA, Iwate University, 4-3-5, Ueda, Morioka, Iwate

Kiyoshi HOSHI, Nissan Motor Co., Ltd

\section{1 . 緒 言}

傾斜機能材料(FGM)は，所要の機能を発現するために材 料組成が連続的かつ滑らかに変化しているが，合成法によ っては，逆にそのため材料内での拡散によって材料の組成 分布を設計通りに合成することは容易ではなく，得られた FGM の特性を評価することが必須になっている。しかし， 機械的特性, 熱的特性に限らず，従来の特性評価法は使用 できず，いずれも新たに評価法（測定法）を開発せねばな らない。そこで，著者らは前報において非定常温度分布の 情報から，FGM 平板の板厚方向の熱伝導率分布を逆決定す る手法を，著者らが開発した FGM 平板の非定常熱伝導問題 に対する区分的非線形不均質近似法(PNNA 法) ${ }^{(1)}$ と遺伝的ア ルゴリズム $(\mathrm{GA})$ を併用することにより確立した。しかし， この方法では FGM 平板内部の測定温度の情報を必要とする ために，薄いFGM 平板に穴を開ける必要があり，これによ って温度分布が乱される䀣念がある。そこで本研究では, 加熱された FGM 平板の外観形状から入手可能なデータとし て熱曲げ曲率を採用し，この曲率から材料組成分布を同定 する手法を提案する。材料組成分布を逆決定する過程にお いて必要な FGM 平板の非定常温度場の解析には, PNNA 法 を採用し，物性値の温度依存性を考慮した熱曲げ曲率，熱 応力の解析式は本研究において導出した。

\section{2.問題設定と解析}

図 1 に示すように厚さh $\mathrm{h}$ FGM 平板の板厚方向に $\mathrm{x}$ 座標 を持つ座標系を設定し，初期温度が一様に0であり，板厚

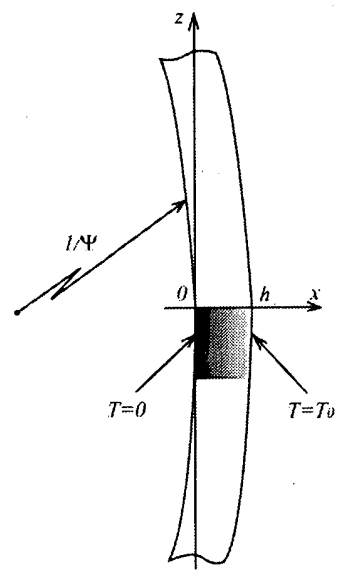

Fig.1 FGM Plate subjected to thermal bending 方向に不均質性を有する FGM 平板の片側表面が $\mathrm{T}_{0}$ に加熱
され，他方の表面が強制冷却されて初期温度に保持される 場合を考える。この場合に FGM 平板に生じる熱曲げ曲率か ら，FGM 平板の材料組成分布を同定する手法を提案する。

2.1FGM 平板の温度解析＼cjkstart非定常温度場に及ぼす物性值の 温度依存性の影響は小さいことから，温度場の解析は物性 值の温度依存性を考慮せず, PNNA 法(1)を採用して解析する。 板厚方向に任意の物性值分布を持つ FGM 平板の非定常温度 場が満足すべき基礎式は，

$\left.\begin{array}{l}\frac{\partial}{\partial x}\left\{\lambda(x) \frac{\partial T}{\partial x}\right\}=c(x) \rho(x) \frac{\partial T}{\partial t} \\ T=0, t=0 \\ T=0, x=0 ; \quad T=T_{0} H(t), x=h\end{array}\right\}$

ここで， $\lambda, \rho, c$ はそれぞれ熱伝導率，密度，比熱であり， H( ) は Heaviside のステップ関数を表す。PNNA 法の採用に際し て, $x=x_{g}$ において FGM 平板を 2 層に分割し, 各層の不均 質熱伝導率を以下のように表現する。

$$
\lambda_{i}(x)=a_{i}\left(x-b_{i}\right)^{n_{i}} \quad(i=1,2)
$$

ここで, $a_{i}, b_{i}, n_{i}$ は任意定数であり,$x_{g}$ も任意である。

2.2 熱店力・熱曲げ曲率前述の非定常温度場を受け，外 力の作用しない薄い FGM 平板の物性值の温度依存性を考慮 した熱応力 $\sigma_{f}(x, t)=\sigma_{y y}=\sigma_{z z}$ は, 次式のように導出される。 $\sigma_{f}=\frac{E(x, T)}{1-v(x, T)}\left[-\int_{0}^{T(x, l)} \alpha(x, T) d T+\frac{\left(I_{1} x-I_{2}\right) M_{0}+\left(I_{1}-I_{0} x\right) M_{1}}{I_{1}^{2}-I_{0} I_{2}}\right]$ また，端面の合力と合モーメントをそれぞれ $\mathrm{F}^{\mathrm{ap}}, \mathrm{M}^{\mathrm{ap}}$ とすれ ば, 物性值の温度依存性を考慮した熱曲げ曲率 $\Psi$ は次式の ように導出される。

$$
\Psi=\frac{I_{1}\left(M_{0}+F^{a p}\right)-I_{0}\left(M_{1}+M^{a p}\right)}{I_{1}^{2}-I_{0} I_{2}}
$$

ここで, 


$$
\left.\begin{array}{l}
I_{i}=\int_{0}^{h} \frac{x^{i} E(x, T)}{1-v(x, T)} d x, \quad(i=0,1,2) \\
M_{i}=\int_{0}^{h} \frac{x^{i} E(x, T)}{1-v(x, T)} \int_{0}^{T(x, t)} \alpha(x, T) d T d x, \quad(i=0,1) \\
F^{a p}=\int_{0}^{h} \sigma_{f}(x, t) d x, \quad M^{a p}=\int_{0}^{h} \sigma_{f}(x, t) x d x
\end{array}\right\}
$$

なお，物性值の温度依存性が考慮されないFGM 平板の曲率 は Suresh \& Mortensen ${ }^{(2)}$ により報告されている。

\section{3.材料組成分布の逆決定}

セラミックの組成分布が上に凸である FGM 平板の材料組 成分布を任意に表現するために，各層のセラミックの体積 分率分布を次式のような座標 $x$ の $\mathrm{N}$ 次式で近似する。

$$
V_{i}=A_{i}\left(x-B_{i}\right)^{N_{i}}+C_{i} \quad(i=1,2)
$$

ここで, $A_{i}, B_{i}, C_{i}, N_{i}$ は定数である。仮想界面 $x=x_{g}$ におい て体積分率 $V_{i}$ が連続することから，次式を満足する。

$$
V_{i}=0, x=0 ; V_{i}=1, x=h ; V_{1}=V_{2}, x=x_{g}
$$

次の $\mathrm{GA}$ の計算アルゴリズムにより，测定データとして 与えられる熱曲げ曲率を持つ，最適な材料組成分布に対す る係数 $A_{i}, B_{i}, N_{i}$ と仮想界面の位置 $x_{g}$ を探索する。

step 1 : 熱曲げ曲率の測定データを入力

step2：材料組成分布の情報を持つ初期個体を生成

step3：各組成分布を持つ個体に対する FGM の物性值分布 を Mori-Tanaka の式から導出

step4：各個体に対する熱曲げ曲率を解析

step5 : 各個体の評価

step6 : 収束判定

step7 : 選択, 交叉, 突然変異により次世代の個体を生成

まず step1 から step7 まで計算処理をし, step6 の収束判定 条件を満足しないと，これを満足するまで step3 から step7 を繰り返す。評価は，次式の評価関数 $\Phi$ にり行う。

$$
\Phi=1 / \sum_{i=1}^{N_{t}} \phi\left(t_{i}\right), \quad \phi\left(t_{i}\right)=\left|\Psi_{g i v}\left(t_{i}\right)-\Psi_{i n v}\left(t_{i}\right)\right|
$$

ここで， $N_{l}$ は時間点の個数， $\Psi_{g i v}$ は熱曲げ曲率の測定值， $\Psi_{i n \nu}$ は同定された熱曲げ曲率である。step6 の収束判定条件 は, 評価関数 $\Phi$ の值が最大である個体の，最も大きい $\phi$ の 值が，ある設定值以下に到達したかどうかで判断する。

\section{4 .材料組成分布の逆決定例}

PSZ/SUS304 FGM 平板の材料組成分布を逆決定するに際 して，まず次式の材料組成分布をもつ FGM 平板について非 定常温度, 熱応力, 熱曲げ曲率を順解析し, 得られた各材 料組成分布に対する曲率を測定された熱曲げ曲率の入力デ 一タとして使用して，材料組成分布の同定を行った。

$$
\left.\begin{array}{ll}
V_{p s z}(\varsigma)=1-(1-\varsigma)^{\eta_{R}} & {[\text { ceramic }- \text { rich }]} \\
V_{p s z}(\varsigma)=\varsigma^{\eta_{P}} & {[\text { ceramic }- \text { poor }]}
\end{array}\right\}
$$

図 2 は, 物性値の温度依存性を考慮しない場合の熱曲げ 曲率から同定された FGM 平板の材料組成分布を示す。図中 の実線は同定された材料組成分布，点線は入力データとし て使用する熱曲げ曲率を順解析するために使用した式(9)で 与えられる材料組成分布である。また，同定された材料組 成分布から計算された熱曲げ曲率の入力データに対する相 対誤差を表 1 に示した。図 2 (b)の ceramic-poor $\eta_{p}=2$ の場 合を除いて非常に精度良く同定されている。

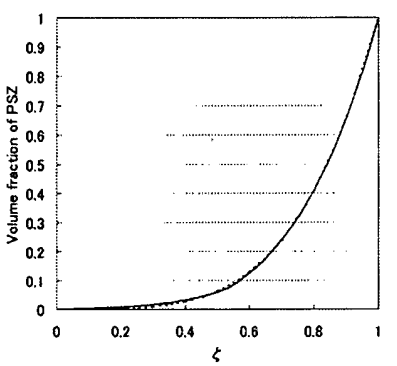

(a)Ceramic-poor $\eta_{p}=4$

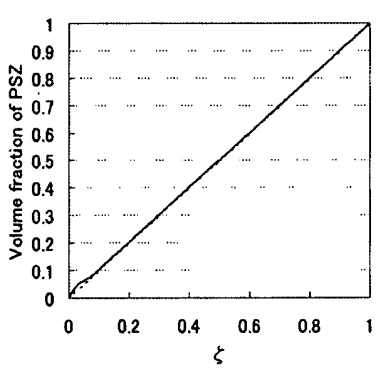

(c) Linear $\eta_{R}=\eta_{P}=1$

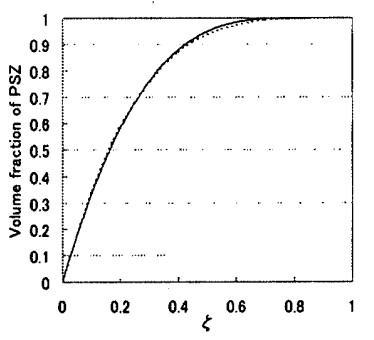

(e)Ceramic-rich $\eta_{R}=4$

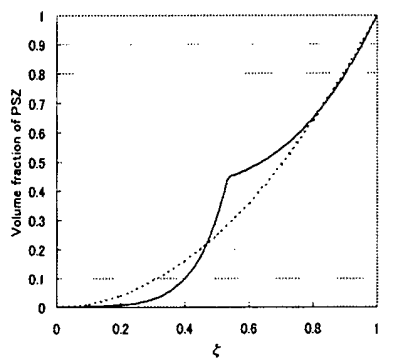

(b)Ceramic-poor $\boldsymbol{\eta}_{p}=2$

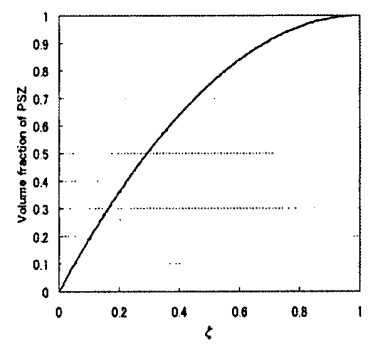

(d)Ceramic-rich $\eta_{R}=2$

Fig.2 Material composition determined inversely and exact material composition
Table 1 Relative error of curvature (\%)

\begin{tabular}{|c|c:c:c:c:c|}
\hline$\tau$ & Poor 4 & Poor 2 & Linear & Rich 2 & Rich 4 \\
\hline 0.01 & 0.044 & 0.915 & 0.063 & 0.000 & 0.018 \\
0.05 & 0.049 & 0.087 & 0.105 & 0.000 & 0.014 \\
0.1 & 0.047 & 0.010 & 0.114 & 0.000 & 0.031 \\
\hline 0.25 & 0.122 & 0.756 & 0.080 & 0.000 & 0.084 \\
\hline 0.5 & 0.107 & 0.336 & 0.059 & 0.000 & 0.023 \\
1 & 0.108 & 0.032 & 0.052 & 0.000 & 0.029 \\
\hline 2 & 0.109 & 0.003 & 0.050 & 0.000 & 0.046 \\
\hline 3 & 0.109 & 0.003 & 0.049 & 0.000 & 0.049 \\
5 & 0.109 & 0.003 & 0.049 & 0.000 & 0.049 \\
\hline 100 & 0.109 & 0.003 & 0.049 & 0.000 & 0.049 \\
\hline
\end{tabular}

\section{5.結 言}

1. 材料組成分布を精度良く同定するためには，過渡状態の 熱曲げ曲率を精度良く表現できることが重要である。

2. 熱曲げ曲率に対しては高温側の材料組成分布が重要であ るため，相対誤差 $0.1 \%$ オーダーで熱曲げ曲率を一致さ せなければ,低温側の材料組成分布は正しく同定されない。 参考文献 省略 